\title{
Developing Core Stability Exercise Model of Playing Approach for Children Aged 10-12 Years to Improve Accuracy in 15 Meters Archery
}

\author{
Oktita Indah Pratiwi \\ Master Program in Sport Sciences \\ Universitas Negeri Yogyakarta \\ Yogyakarta, Indonesia \\ oktita0131pasca2015@student.uny.ac.id
}

\author{
Mansur \\ Faculty of Sport Sciences \\ Universitas Negeri Yogyakarta \\ Yoyakarta, Indonesia \\ mansur@uny.ac.id
}

\begin{abstract}
Core Stability Exercise Approach for Playing at age 10-12 with the aim of improving the accuracy at an arching distance of 15 meters, to develop physical exercise by involving a circuit training with the concept of play, and also developing physical training by practicing more often to improve the results from a scoring distance of 15 meters. This is a Research and Development (RND) study that comprises of a number of stages, namely: preliminary stage research consists of data collection via field study and needs analysis, planning stage; development stage (collection of theories related to the research), validation experts, phase 1 revisions, small-scale trials, phase 2 revisions, large-scale trials, end products, and product dissemination. This final product is packaged in hand book and DVD recording. The case studies used in this research are Archery Laboratory School of FIK UNY and SD Muhammadiyah Sapen Yogyakarta. The sampling technique employed here is purposive sampling. A small group trial was conducted involving 10 children with ages ranging from 10 to 12 years from Selabora Panahan FIK UNY. Also, large group trials were conducted involving 36 children and 2 archery trainers. The data collected were results of large group trial video tapes from the field, employing questionnaires on smallscale testing of $82 \%$, large-scale of $97.77 \%$ and 2 coaches $95 \%$ and $92 \%$. In general, the product can be used and rated as Very Good, an expert validation sheet containing $86 \%$ and $88 \%$ product feasibility levels can be used with the Good category. Effectiveness test on large group of Sig. (2-tailed) $0,001<0,05$ and $0,002<0,05$ can be concluded that giving treatment model of core stability exercises with play approach is feasible to be used and effective model can increase yield score of archery score of $\mathbf{1 5}$ meters distance.
\end{abstract}

Keywords — core stability exercise, accuracy, archery

\section{INTRODUCTION}

People's opinion of Archery Sports is often related to training focus, concentration and beneficial for physical fitness. Archery is a sport that is in high demand in every region and has therefore been developing as rapidly as the field of technology. The interest shown in archery makes it one of the most liked sports by people of all age groups including children, adolescents and adults. Unsurprisingly, archery has been useful as a form of recreation and entertainment. Young talented archery shooters are discovered through extracurricular activities in schools and sports clubs that foster prospective for archery athletes, in addition to the several beginner and pre-beginner competitions routinely carried out by PERPANI to attract talented athletes, especially in Yogyakarta Special Region (DIY).

Beginners and pre-beginner athletes of archery are often tested at the regional and national levels because they are mostly in the children's age group ranging from 6 to 12 years. There is a relatively high tendency for children to grow into a body structure having certain characteristics that correlate with the conformity to pursue certain sports. Children's abilities develop as their body grows into maturity. By engaging in certain sports at an early age, the child has been able to control the physical growth, balance and physical abilities (especially strength, flexibility, balance and ability to throw / gross motor skill) to grow quite rapidly [1]

Archery's beginner classes focus more on children within the age group of 10-12 years. During that age, children tend to experience rapid growth in the phase of both physical growth and development. Judging from physical growth, girls seem to experience rapid growth from the age of 10 to 13 years while boys experience rapid growth from 12 to 15 years [2].

[3] In general, at the age of 10 to 12 years, children begin to show manipulative skills resembling adult features. They begin to display fast, complex, and complicated movements required to produce good quality crafts or play certain musical instruments. Practicing at an early age therefore enhances motoric development which helps children grow rapidly and develop coordination. Archery develops the eyesight, handling and body coordination. Although archery is introduced at upper class elementary school, based on research, this does not mean that children cannot be involved in exercises, "As a matter of fact, childhood is the most physically active period in human growth" [2].

Based on interviews with parents and coaches of archery sports clubs in FIK UNY Selabora Archery and extracurricular Archery of Sapen Muhammadiyah Elementary School Yogyakarta, archery sports are used as a means of engagement during free time, a mode of training focus, and not surprisingly also enhances developments that can be beneficial for the child.

Sports have a major influence in determining the future of children. Archery sports can be easily perceived ass the repetition of pulling and releasing arrows, and how boring would it seem if it is not presented in attractive ways to kids, 
or at least intertwined with other fun activities involving physical exercise.

An article by Pangrazi, Robert P. and Dauer, Victor P, 1989 in the journal "Movement in Early Childhood and Primary Education" stated that only a few children keep up with the habit of exercising after the age of 10 . They are less resistant to physical activities during their adulthood as many children claim that they don't exercise (bored) because the activities are boring. Archery sport does not only require the application of technical training, but physical training is also needed for developing strength, endurance, coordination and stability.

Based on observations of researchers and interviews with archery clubs and schools in Yogyakarta, a number of trainers have not involved attractive physical activities in their training, and with that, children are less motivated and uninterested in participating in physical activities. It is in the nature of children to complain and show a trivial attitude towards carrying out physical activities put in place by the teacher/trainer. The trainer must also be knowledgeable about conducting physical trainings in a fun way to provide benefits in form of arm muscle strength, coordination improvement, muscular strength, balance, increase motivation, creativity and pleasure.

Some literatures promote physical training that aid in the stimulation of brain development and motion such as: ballet, rhythmic gymnastics, swimming, soccer, volleyball, athletics, martial arts, tennis, and archery. Abilities in the listed sports above can be measured through several tests and physical exercise programs to produce effective and efficient movements.

In this field, core is a general term often used to refer to all muscles of the outer body which includes the shoulder, back, abdominal, and hip. It has been scientifically proven that endurance training (also known as strength training) can be safe and effective for boys, men and women provided proper training guidelines are being followed. This indicates that safely incorporating core stability exercises into a physical education curriculum is a valid means of promoting physical fitness in children [4]. These discoveries are very relevant practices for designing activities for physical education lessons for children. Also, they are essential for muscle fitness which is a fundamental component in health related fitness that contributes to daily life tasks, participation in recreational activities and suppression of illnesses.

Some of these studies have succeeded in measuring abdominal muscles required for stabilising the lumbar spine by increasing the intra-abdominal pressure to maintain the straight lumbar spine and also avoid a cycle of rotation during physical activities. A simple exercise that is commonly used for strengthening the abdominal muscles (rectus abdominus, internal / external obliques, and transverse abdominus) is the isometric or "static" position known as Planking. This form of exercise has often been included in training programs, especially archery sports.

Examples of physical exercises often applied in archery training for children are sit-ups, push-ups, back up and bow training. Based on a survey conducted in the Yogyakarta Special Region by researchers on several archery clubs it is understood that the components in physical training such as repitition, number of sets and duration for children archery athletes are identical with those for adolescent athletes. This indicates that the forms of formal movements without the involvement of elements of play are not in accordance with the stage of growth and development of athletes within the range of 10-12 years. Therefore, these methods and targets are inappropriate for children i.e. this form of exercise that has been implemented is not optimal. Another issue is that some trainers possess inadequate knowledge and ability to conduct the proper physical training programs. Therefore, the author here modifies the form of physical training ny introducing a touch of excitement packaged in the form of play, and the research titled Development of Core Stabiliy Exercises (CSE) approach to play at the age of 10-12 years to improve accuracy in 15 meters archery.

\section{METHODS}

This is a Research and Development (RND) research that was adopted from the development stages proposed by Gall, Gall, \& Borg [5]. The preliminary stage research comprises of data collection (via field study and analysing needs), planning phase, development phase (collection of product-related theories), expert validation, revision phase 1, small-scale trials, revision phase 2, large-scale trials, final products and product dissemination. Research length was from October to December 2017.

The sampling technique employed in this research is principally purposive sampling. This sampling method is specifically chosen based on the research objectives [6].

Types of data were in accordance with the objectives of this development study. The collected data are categorised into 2, namely: Qualitative and Quantitative data. The qualitative data utilized in this study comprises of data gathered from assessments and inputs by experts who are multilateral physical trainers and archery trainers (practitioners). On the other hand, the quantitative data used were responses from students and 2 archery trainers at school and selabora regarding core stabiliy exercises approach to play models. To test the efficiency of products used through qualitative descriptive such as the results of the pretest and posttest design on the accuracy of archery shots fired from meters out.

TABLE I. NORM PRESENTATION

\begin{tabular}{|c|c|c|}
\hline Presentase & Klasifikasi & Makna \\
\hline $0-20 \%$ & Not good & canceled \\
\hline $20,1-40 \%$ & poorly & repaired \\
\hline $40,1-70 \%$ & Good enough & used (conditional) \\
\hline $70,1-90 \%$ & Good & used \\
\hline $90,1-100 \%$ & Very Good & used \\
\hline
\end{tabular}

The instruments used in this study are as follows: Questionnaire of value scale 1-5 contained questionnaire information of 1: not good, 2: poorly, 3 good enough, 4: good and 5: very good. This validation is presented to experts and archery trainers (practitioners) to assess whether the game model is in accordance with the supposed features, so the new core stabiliy exercises can be tested. A direct observation technique with the model implementation observation sheet is employed for observing the implementation of the exercise 
using a core stability exercise model with the form of play. The trainer observation sheet was used for obtaining data on the level of feasibility of the draft model developed in actual conditions/field. Product Appraisal Instrument is designed with the product appraisal format of a choice (Yes/no) with 10 items provided for the child to measure the performance and responses of children towards the implementation of the model. The scoring value: this is the result of a 15-meter shooting range on a large-scale trial after $8 x$ treatment with pre post design to test the efficiency of the product that is being developed.

Methods of data analysis employed in this study belong to the qualitative descriptive analysis category. Qualitative descriptive analysis was used in the analysing of the preliminary study questionnaires. At the validation stage of the draft model, in order to measure the feasibility of the obtained data, the data will be displayed in the form of data presentation then analysed qualitatively with the final results as a percentage, then categorised. In both small and large scale tests, the results derived from the conducted trial were analysed with the use of a descriptive analysis approach and qualitative analysis (statistics). On a large scale test where $8 x$ physical exercise treatments were given to decide the efficiency of the product, a qualitative descriptive analysis approach (Kolmogrov-Smirnov Test with Asymp value criteria) was engaged to test the normality of the data. Sig with 0.05 criteria accepts research questions if Asymp. Sig> 0.05 .

\section{RESULT AND DISCUSSION}

Initial Product Development Results: Core stability exercise model is a form of modified physical activity established towards improving the physical fitness of youths nationwide [7]. This modified physical activity is a form of movement that was originally utilized as a health therapy for healing back injuries. Movements classified under the Core Stability Exercise Model are: Abdominal Crunches, bridge, side plank, modified plank, plank, quadruped, superman, bicycle crunch and segmental rotation movements. The above movement used to be executed in a form of static movements, then the researchers established a form of core stability exercise which is carried out through a dynamic movement approach in archery sports for playgroups with children of ages 10-12 years. This activity is a method of training that involves the use of 10 posts, which is where the game derives its name "TAAMAN1-10". The physical activity is considered done when the child has sequentially passed through each post. The title of the movement is modified according to the author's design.

\section{Product Expert Validation}

The analysed results from the filled out questionnaires revealed $86 \%$ physical and multilateral trainers with good categories and $88 \%$ archery sport practitioners with good categories. From the obtain results, it can be concluded that this is a feasible model for use and also field trials with revisions according to suggestions.

\section{Product Revision by Expert}

The product revision process involves receiving advice from physical and multilateral trainer experts as follows: The product revision/model conducted by the researcher is done through a training duration ranging from 15 to 30 seconds in a progressive manner which can also be determined from the start (eg 15 seconds). A product revision or model is conducted by researchers in form of a game model that meets the elements of safety and there must be clear rules avoiding the use of dangerous tools. The product revision or model conducted by researchers is established in the sequence of circuit training and is important that it emphasises systematically on arms, legs and the body as a whole. This revision led by researchers is well detailed in the guidebook to include both warming up and colling down movements.

\section{Small Group Trial Results.}

Based on the obtained results from the questionnaires filled by the athletes, the rate of answered questions according to the aspects assessed was $82 \%$. Based on the criteria set, the core stability exercise development model reformed with a fun approach significantly meets the criteria to be used for 10 12 year old chidren.

\section{Large Group Trial Data}

From the conducted large group trials, questionnaire results were obtained from 36 athletic respondents deriving at a rate of $97.77 \%$. This depicts that this model can be put to use and essentially meets the set criteria. Then feasibility of the response or percentage assessment by archery trainer SD Muhammadiyah sapen Yogyakarta FIK UNY is then put to a test, deriving at a rate of $92 \%$ with very good criteria.

\section{TABLE II. The Percentage of Large Scale Test}

\begin{tabular}{|c|c|c|c|}
\hline Subject & $\begin{array}{c}\text { Percentage } \\
\text { Score }\end{array}$ & Clasification & Meaning \\
\hline 36 Atheletes & $97,77 \%$ & Very Good & Used \\
\hline
\end{tabular}

TABLE III. The PERCENTAGE OF ClASSIFICATION SCORE OF COACHES

\begin{tabular}{|c|c|c|c|}
\hline Subject & $\begin{array}{c}\text { Percentage } \\
\text { Score }\end{array}$ & Clasification & Meaning \\
\hline Selabora Coach & $95 \%$ & Very Good & Used \\
\hline Sapen Coach & $95 \%$ & Very Good & Used \\
\hline
\end{tabular}

In accordance with the criteria that have been set in the trial run, the modified core stability exercises that have been equipped with a fun approach for athletes of ages 10-12 years have sufficiently met the criteria, and this depicts that this model can be put to use or included in the physical activity program for children aged 10-12 years in the upper class of SD Muhammadiyah Sapen and selabora archery FIK UNY.

Product Effectiveness Test Data in Large Group Trials (10-12 Years Children)

Calculation Results of the Normality Test for large groups of Kolmogrov-Smirnov Test data. Based on the results illustrated in the table below, it can be observed that each group, with a total sample of 36 children, has Asyimp. Sig> 0.05 , and can also be seen that the data group is normally distributed, meaning that the group data is standard. 
Test Results of Research Questions (test)

TABLE IV. THE RESULT OF NORMALITY DATA TEST ANALYSIS

\begin{tabular}{|l|c|c|}
\hline \multicolumn{1}{|c|}{ Variabel } & Significancy & Clasification \\
\hline Selabora Archery FIK UNY (pretest) & 0.173 & Normal \\
\hline Archery SD Muh Sapen (pretest) & 0.200 & Normal \\
\hline Selabora Archery FIK UNY (posttest) & 0.200 & Normal \\
\hline Archery SD Muh Sapen (posttest) & 0.200 & Normal \\
\hline
\end{tabular}

Answering the research questions that have been composed by the researcher, then its left for the Test-t analysis to figure out, "Is this result efficient and feasible enough for the physical activity of core stability exercises to be conducted with a play approach?" After the finished product, the archery score is pre-tested, and then treat for $8 \mathrm{x}$ meetings ending with a post-test at a 15 meters range.

Below is an illustration of the results of the T-Test:

TABLE V. THE SUMMARY OF T-TES ANALYSIS RESULT

\begin{tabular}{|l|c|c|}
\hline \multicolumn{1}{|c|}{ Variables } & df & Sig. (2-tailed) \\
\hline Selabora Archery FIK UNY & 17 & 0.001 \\
\hline Archery SD Muh Sapen & 17 & 0.002 \\
\hline
\end{tabular}

Based on the results displayed in the table above, it can be observed that there is a significant difference between the results of the pre-test and post-test scores of 15 meters which indicates that there is an effect of the $8 \mathrm{x}$ treatment meeting on the results of the 15 meters range archery shooting. Therefore, it is known that the value of sig (2-tailed) archery Selabora FIK UNY $0.001<0.05$ and the sig (2-tailed) value of Archery Extracurricular SD muhammadiyah sapen 0.002 $<0.05$.

\section{CONCLUSION}

Testing the feasibility based on the results of expert validation has depicted that the core stability exercises model with the with the modified approach for children at the age of 10-12 years is worthy of use and categorised as high standard. Based on the results of the implementation of the modified approach with a small group trial comprising of a sample of 10 children which developed interest and pleasure in playing, understanding of the rules, interest in the tools

used, usefulness in training the muscles to support archery technique skills, and the desire to repeat the game states that the model is worthy enough to be put to use.

In the trial phase of large groups on the model of development of core stability exercises with a fun oriented approach to children with the age of 10-12 years to improve archery accuracy of 15 meter range comprising of 36 samples and 2 trainers, core stability exercises are classified as well efficient. Based on the analysis of the effectiveness of the modified exercise approach, it can be concluded that it is suitable for use and an efficient model can increase the results of 15 meters archery scores. The results of this product are packaged in the form of handbooks and DVD recordings to enable the model to be easily applied by the trainer.

\section{REFERENCES}

[1] Sugiyanto, Perkembangan dan belajar motorik. Jakarta: Departemen Pendidikan dan Kebudayaan, 1998

[2] Lumintuarsi, Pembinaan multilateral bagi atlet pemula. Yogyakarta: UNY Press, 2013.

[3] Desmita, Psikologi perkembangan. Bandung: Remaja Rosdakarya, 2006.

[4] Ahmadi R. Hidari N. Mahdavi B, daneshmandi H, "The effect of core stabilization exercises on the physical fitness in children 9-12 years," Journal of Sport Medicine, vol. X, no 3, pp.2401-2405, 2014.

[5] Borg, W. R. \& Gall M. D., Educational research anintruction. Fourth Edition. New York: Longman, 2007.

[6] Sugiyono, Metode penelitian kuantitatif, kualitatif dan RnD. Bandung: Alfabeta, 2011.

[7] P. Patricia, R. Nichols, Herman S, "Core for the classroom". Education database pp.23, 2007. 